\title{
ANALISIS FAKTOR-FAKTOR YANG MEMENGARUHI KEPUASAN PENGGUNA SISTEM AKUNTANSI INSTANSI BASIS AKRUAL (SAIBA) DENGAN MODEL END-USER COMPUTING SATISFACTION
}

\author{
Gigih Alfrian Pratama Putra \\ Direktorat Akuntansi dan Pelaporan Keuangan \\ Alamat korespondensi: gigihalfrian@gmail.com
}

\section{INFORMASI ARTIKEL}

Diterima Pertama

13 Juni 2016

Dinyatakan Diterima

7 Desember 2017

KATA KUNCI:

SAIBA, Kepuasan Pengguna, End-User Computing Satisfaction.

KLASIFIKASI JEL:

M48, M410.

\begin{abstract}
ABSTRAK
Research of Accrual Based Institution Accounting System (SAIBA) as a new mandatory information system released in 2015 and will produce various satisfaction among application users. The satisfaction of application user of information system is the most important thing in the success of the information system. This study examines the causes of the satisfaction of KPPN operators in the scope of Aceh Province based on the factors that influence it with the End User-Computing Satisfaction (EUCS) approach. The statistical test was conducted by using SPSS 22. Based on interviews / questionarry to 209 respondents, the result showed that the accuracy, format, and ease of use of the application had a positive effect on SAIBA user satisfaction KPPN Type A1, while KPPN Type A2, the format and timeliness had positive effect on user satisfaction.
\end{abstract}

Penelitian Sistem Akuntansi Instansi Basis Akrual (SAIBA) sebagai sistem informasi yang baru dirilis tahun 2015 dan bersifat mandatory akan menghasilkan kepuasan yang beragam di kalangan pengguna aplikasi. Kepuasan operator aplikasi selaku pengguna sistem informasi merupakan hal terpenting dalam mewujudkan kesuksesan sistem informasi tersebut. Penelitian ini akan mengkaji penyebab kepuasan operator satuan kerja KPPN lingkup Provinsi Aceh berdasarkan faktor-faktor yang memengaruhinya dengan pendekatan model End-User Computing Satisfaction (EUCS). Uji statistik dilakukan dengan menggunakan SPSS 22. Hasil penelitian dari 209 data responden yang diterima menunjukkan bahwa akurasi, format, dan kemudahan penggunaan aplikasi berpengaruh positif terhadap kepuasan pengguna SAIBA di lingkup KPPN Tipe A1. Sedangkan di lingkup KPPN Tipe A2, format dan ketepatwaktuan berpengaruh positif terhadap kepuasan pengguna. 


\section{PENDAHULUAN}

Basis akuntansi sektor publik di Indonesia telah berubah menjadi basis akrual di tahun 2015 Perubahan tersebut mengakibatkan adanya penyesuaian pada penatausahaan dan pelaporan pertanggungjawaban pelaksanaan anggaran. Guna memenuhi perubahan basis akuntansi tersebut, Ditjen Perbendaharaan membangun suatu sistem informasi akuntansi yang disebut Sistem Akuntansi Instansi Basis Akrual (SAIBA).

SAIBA yang bersifat mandatory harus diimplementasikan oleh satuan kerja secara menyeluruh di tahun 2015. Keberadaan SAIBA menuai respon dan tanggapan yang beragam dari pengguna maupun pengembang aplikasi. Pemahaman dan kemampuan operator yang berbeda-beda terhadap SAIBA menjadi perhatian bagi pihak pengembang karena hal tersebut menentukan tingkat kepuasan para pengguna sistem informasi.

Kepuasan pengguna sistem informasi diketahui sebagai faktor yang sangat berpengaruh terhadap kesuksesan suatu sistem (Petter et al, 2008), sehingga jika pengguna tersebut merasa puas maka sistem tersebut telah sukses. Kepuasan pengguna sistem informasi juga berperan sebagai alat ukur pengganti efektivitas suatu sistem informasi (Istianingsih dan Utami, 2010).

End-User Computing Satisfaction adalah model yang dikembangkan oleh Doll dan Torkzadeh (1988) dengan cara melakukan penelitian terhadap 618 responden dan menghasilkan dua belas item pertanyaan dan terbagi dalam lima komponen, yakni content, accuracy, format, ease of use, dan timeliness. Beberapa penelitian perihal pengukuran keberhasilan sistem informasi menggunakan instrumen kepuasan pengguna dari Doll dan Torkzadeh juga dilakukan oleh Sommers, Nelson, dan Karimi (2003), serta Istianingsih dan Wijanto (2008). Model EUCS juga digunakan dalam penelitian sistem akuntansi sektor publik di Malaysia oleh Ilias dan Razak (2011) yang menyimpulkan bahwa kelima komponen masih valid.

\section{LANDASAN TEORI}

\subsection{Sistem Informasi Akuntansi}

McLeod (2004) menjelaskan sistem sebagai sekelompok elemen yang terintegrasi untuk mencapai suatu tujuan. Informasi adalah data yang telah diolah menjadi bentuk yang memiliki arti dan bermanfaat, baik saat ini maupun di masa yang akan datang (McLeod, 2004). Accounting Principles Boards (APB) pada tahun 1970 menyatakan bahwa akuntansi adalah suatu aktivitas jasa yang berfungsi menyediakan informasi kuantitatif utamanya informasi keuangan yang dapat digunakan untuk membuat keputusan ekonomi dan menentukan pilihan yang beralasan di antara alternatif tindakan yang dapat diambil. Sistem Informasi Akuntansi didefinisikan sebagai sistem yang digunakan untuk mencatat dan mengolah data transaksi serta menyiapkan informasi yang berguna bagi para pemangku kepentingan suatu perusahaan dalam mengambil keputusan (Winarno, 2006).

Definisi lain dari Sistem Informasi Akuntansi adalah sekumpulan sumber daya yang diatur untuk mengolah data menjadi informasi (Mujilan, 2012). Sistem Informasi Akuntansi berperan penting bagi organisasi terkait penatausahaan sumber daya yang dimiliki organisasi untuk dilaporkan sebagai informasi yang bermanfaat sehingga dapat diambil tindak lanjut oleh para pengambil keputusan. Jogiyanto (2008) sebagaimana dikutip oleh Mujilan (2012) menyarankan bahwa perusahaan seyogyanya membangun sistem informasi akuntansi terlebih dahulu sebelum membangun sistem informasi manajemen di perusahaan tersebut.

\subsection{Sistem Akuntansi Pemerintahan}

Sistem Akuntansi Pemerintah menurut Peraturan Pemerintah Nomor 71 Tahun 2010 tentang Standar Akuntansi Pemerintahan (SAP) pasal 1 ayat 11 didefinisikan sebagai "Rangkaian sistematik dari prosedur, penyelenggara, peralatan, dan elemen lain untuk mewujudkan fungsi akuntansi sejak analisis transaksi sampai dengan pelaporan keuangan di lingkungan organisasi pemerintah". Dalam peraturan tersebut disebutkan bahwa pemerintah menyusun sistem akuntansi pemerintahan dengan mengacu pada SAP.

Sistem Akuntansi Pemerintah Pusat didefinisikan dalam Peraturan Menteri Keuangan Nomor 171 Tahun 2007 tentang Sistem Akuntansi dan Pelaporan Keuangan Pemerintah Pusat sebagai "Serangkaian prosedur manual maupun terkomputerisasi mulai dari pengumpulan data, pencatatan, pengikhtisaran, sampai dengan pelaporan posisi keuangan dan operasi keuangan Pemerintah Pusat". Sistem Akuntansi Pemerintah Pusat digunakan untuk menyusun Laporan Keuangan Pemerintah Pusat (LKPP) dengan basis akrual yang terdiri dari Laporan Arus Kas, Laporan Realisasi Anggaran, Laporan Operasional, Laporan Perubahan Ekuitas, Laporan Perubahan SAL, dan Neraca, serta Catatan atas Laporan Keuangan (CaLK).

Sistem Akuntansi Instansi merupakan bagian dari Sistem Akuntansi Pemerintah Pusat. SAI 
dijalankan oleh kementerian/lembaga sebagai instansi yang melaksanakan APBN. Serangkaian prosedur manual maupun yang terkomputerisasi mulai dari pengumpulan data, pencatatan, pengikhtisaran, sampai dengan pelaporan posisi keuangan dan operasi keuangan pada Kementerian Negara/Lembaga adalah definisi SAI yang mengacu pada Peraturan Menteri Keuangan Nomor 59 Tahun 2005.

SAI memiliki dua sub sistem, yaitu Sistem Akuntansi Keuangan dan Sistem Akuntansi Barang Milik Negara. Kedua sistem tersebut menghasilkan laporan yang saling melengkapi satu sama lain dan pada tingkat kementerian akan dikonsolidasikan menjadi Laporan Keuangan Kementerian/Lembaga (LKK/L). Satuan kerja selaku unit akuntansi menyampaikan laporan kepada KPPN untuk dilakukan rekonsiliasi setiap bulan dan juga bertindak sebagai unit akuntansi pengguna barang untuk dilaporkan kepada KPKNL setiap semester.

\subsection{Sistem Akuntansi Instansi Basis Akrual (SAIBA)}

Direktorat Jenderal Perbendaharaan adalah instansi yang berwenang untuk membangun sistem terkait implementasi SAP Basis Akrual untuk digunakan oleh setiap satuan kerja di kementerian/lembaga. Sistem yang baru tersebut menghasilkan laporan keuangan sesuai Peraturan Pemerintah Nomor 71 Tahun 2010. SAIBA memiliki beberapa tujuan dalam implementasinya, salah satu tujuannya adalah sebagai sistem yang membantu operator satuan kerja selaku entitas akuntansi/pelaporan dalam penyusunan laporan keuangan berbasis akuntansi akrual pada masa transisi/awal implementasi.

Tujuan lain dari sistem ini adalah menciptakan keseragaman sistem yang berfungsi untuk menatausahakan pelaksanaan anggaran sehingga kualitas laporan keuangan pada tataran satuan kerja, wilayah, eselon I, hingga kementerian/lembaga dapat ditingkatkan. Pengguna dari aplikasi SAIBA adalah kementerian/lembaga selaku Unit Akuntansi Pengguna Anggaran (UAPA), Unit Eselon I pada kementerian/lembaga selaku Unit Akuntansi Pembantu Pengguna Anggaran Eselon I (UAPPAE1), kantor wilayah dari masing-masing Unit Eselon I selaku Unit Akuntansi Pembantu Pengguna Anggaran Wilayah (UAPPA-W) dan tingkatan terakhir adalah satuan kerja yang bertindak sebagai Unit Akuntansi Kuasa Pengguna Anggaran (UAKPA).

SAIBA merupakan sistem baru yang mulai dijalankan pada tahun 2015 dalam rangka penerapan basis akuntansi akrual dan bersifat sementara, sedangkan Sistem Akuntansi Tingkat
Instansi (SAKTI) merupakan sistem aplikasi terintegrasi yang bersifat permanen. Dikarenakan SAKTI belum dapat dijalankan, maka laporan keuangan disusun menggunakan SAIBA sesuai dengan bunyi pasal 5 Peraturan Menteri Keuangan Nomor 270 Tahun 2014 tentang Penerapan Standar Akuntansi Pemerintah Basis Akrual pada Pemerintah Pusat.

SAIBA dibangun oleh Direktorat Jenderal Perbendaharaan dan merupakan hasil pengembangan aplikasi akuntansi sebelumnya, yakni Sistem Akuntansi Kuasa Pengguna Anggaran (SAKPA). SAKPA menggunakan basis akuntansi kas menuju akrual, sedangkan SAIBA berbasis akuntansi akrual. SAIBA adalah salah satu sub sistem dari SAI, yaitu Sistem Akuntansi Keuangan. Sub sistem lain adalah SA-BMN dengan aplikasi SIMAK BMN. SAIBA dan SIMAK BMN merupakan aplikasi mandatory yang digunakan masing-masing satuan kerja. SAIBA berperan dalam akuntasi keuangan, sedangkan SIMAK BMN berfungsi sebagai akuntansi barang/aset.

\subsection{Kepuasan Pengguna}

Definisi kepuasan pelanggan diungkapkan Kotler (1997:140) sebagai perasaan senang atau sebaliknya yang berasal dari perbandingan antara kesannya atas kinerja suatu produk. Kepuasan pengguna sistem informasi adalah cara pandang pengguna atas sistem informasi secara nyata dan bukan pada kualitas sistem secara teknik (Guimaraes et al. 2003). Kustono (2000) menjelaskan kepuasan pemakai sebagaimana dikutip Perdanawati (2014) sebagai kesesuaian antara harapan dengan hasil yang diperoleh seseorang.

Pendapat lain terkait kepuasan diuraikan sebagai suatu diskonfirmasi dalam kaitan dengan marketing (Yi, 1990). Yi menjelaskan bahwa kepuasan ditentukan oleh arah dan intensitas dari perbedaan antara kinerja yang diharapkan dengan standar kognitif. Diskonfirmasi dibagi menjadi tiga, yaitu diskonfirmasi positif, diskonfirmasi negatif, dan konfirmasi. Sesuatu keadaan dikatakan diskonfirmasi positif apabila kinerja yang dipersepsikan lebih tinggi dari standar kognitif, sebaliknya jika kinerja yang dipersepsikan lebih rendah dari standar kognitif disebut sebagai diskonfirmasi negatif. Sementara, konfirmasi adalah keadaan dimana kinerja yang dipersepsikan sama dengan standar kognitif. Baik diskonfirmasi positif maupun konfirmasi akan menghasilkan kepuasan, sedangkan diskonfirmasi negatif akan berujung pada ketidakpuasan (Koeswoyo, 2006).

Remenyi et al (2001) mendefinisikan secara spesifik tentang kepuasan pengguna sistem informasi. Mereka berpendapat bahwa kepuasan 
pengguna umumnya adalah hasil perbandingan dari harapan/kebutuhan pengguna sistem informasi terhadap kinerja atau kemampuan yang dirasakan atas sistem informasi tersebut dari beberapa sudut pandang yang berbeda. Dapat disimpulkan bahwa kepuasan pengguna adalah apa yang dirasakan pengguna yang timbul akibat kesesuaian dari kinerja sebuah sistem informasi dibandingkan dengan harapan dan kebutuhan dari pengguna tersebut. Penelitian ini mencoba menggali apakah terdapat kesesuaian antara kinerja sistem informasi dengan harapan pengguna untuk selanjutnya digali faktor yang paling berpengaruh terhadap kepuasan pengguna sistem informasi tersebut.

Kepuasan pengguna adalah salah satu faktor penentu kesuksesan sebuah sistem informasi. Faktor lain adalah tingkat penggunaan dan kebermanfaatan, tetapi faktor tersebut tidak dapat digunakan sebagai proksi utama apabila sistem informasi tersebut bersifat wajib (mandatory). Hal tersebut diungkapkan Koeswoyo (2006) dalam tesisnya yang berjudul "Faktor-faktor yang mempengaruhi kepuasan pemakai software akuntansi".

\subsection{Model Kepuasan Pengguna}

Terdapat beberapa model yang dapat digunakan untuk mengukur tingkat kepuasan pengguna sistem informasi. Setiap model memiliki variabel yang berbeda sebagai dasar pengukuran kepuasan pengguna. Salah satu model tersebut adalah Model End-User Computing Satisfaction (EUCS) yang dikembangkan oleh Doll dan Torkzadeh (1988) dan merupakan salah satu model yang sering diadopsi dalam penelitian mengenai kepuasan pengguna karena model ini lebih sederhana dan mudah diterapkan. Model EUCS masih valid untuk diterapkan sesuai dengan hasil penelitian Xiao da Dasgupta (2002).

Model yang dikembangkan oleh Doll dan Torkzadeh tersebut terbilang cukup lama yakni sejak 1988, akan tetapi instrumen yang digunakan untuk mengukur kepuasan pengguna suatu sistem informasi masih tetap valid. Hal tersebut dibuktikan dengan penelitian yang dilakukan oleh Ilias dan Razak pada tahun 2011, jurnal mereka yang berjudul End-User Computing Satisfaction (EUCS) towards Computerised Accounting System (CAS) in Public Sector: A Validation of Instrument menghasilkan simpulan bahwa lima dimensi yang digunakan dalam pengukuran kepuasan pengguna sistem informasi adalah valid. Lima dimensi yang dimaksud terdiri dari content, accuracy, format, ease of use, dan timeliness.

\subsubsection{Content}

Maksud Content pada penelitian ini adalah tingkat relevansi dan kelengkapan informasi yang dihasilkan sistem dengan kebutuhan para pemakai (Seddon dan Yip, 1992). Kepuasan pengguna dipengaruhi oleh beberapa faktor, salah satunya adalah isi dari informasi yang dihasilkan SAIBA, oleh karena itu, hipotesis yang dikembangkan adalah:

H1: Content berpengaruh positif terhadap kepuasan pengguna SAIBA.

\subsubsection{Accuracy}

Maksud dari akurasi menurut Seddon dan Yip (1992) dalam penelitian ini adalah tingkat keakuratan dari informasi yang dihasilkan oleh sistem. SAIBA sebagai salah satu sistem informasi akan menghasilkan output berupa laporan. Laporan yang akurat akan mempengaruhi tingkat kepuasan pengguna, oleh karena itu, hipotesis yang dikembangkan adalah:

H2: Accuracy berpengaruh positif terhadap kepuasan pengguna SAIBA.

\subsubsection{Format}

Seddon dan Yip (1992) menjelaskan arti dimensi format sebagai salah satu faktor kepuasan pengguna sebagai bentuk dari laporan yang dihasilkan sistem informasi tersebut. SAIBA dirancang untuk menghasilkan laporan yang sesuai dengan peraturan terkait pertanggungjawaban akuntansi akrual, antara lain Laporan Operasional (LO), Laporan Perubahan SAL (LP SAL), Laporan Perubahan Ekuitas (LPE), Laporan Arus Kas (LAK), Laporan Realisasi Anggaran (LRA) dan Neraca, oleh karena itu, hipotesis yang dikembangkan adalah:

H3: Format berpengaruh positif terhadap kepuasan pengguna SAIBA.

\subsubsection{Ease of Use}

Arti dari dimensi Ease of Use adalah seberapa mudah sistem informasi tersebut digunakan (Seddon dan Yip, 1992). Definisi ease of use dijelaskan Davis F.D (1989) sebagai tingkatan kepercayaan seseorang bahwa dengan menggunakan suatu sistem tertentu maka ia akan terbebas dari usaha untuk mengerjakan sesuatu. Dari definisi-definisi di atas, dapat disimpulkan bahwa kemudahan penggunaan akan mengurangi waktu dan tenaga seseorang dalam mempelajari dan menggunakan suatu sistem informasi.

Seseorang lebih cenderung menggunakan teknologi informasi (TI) dalam bekerja dibandingkan dengan tanpa menggunakan TI. 
SAIBA sebagai suatu aplikasi bagi satuan kerja harus dapat digunakan dengan mudah dan menjadi sarana penyusunan laporan pertanggungjawaban atas pelaksanaan anggaran, oleh karena itu hipotesis yang dikembangkan adalah:

H4: Ease of Use berpengaruh positif terhadap kepuasan pengguna SAIBA.

\subsubsection{Timeliness}

Dimensi terakhir dari model end-user computing satisfaction (EUCS) adalah ketepatwaktuan (Timeliness). Maksudnya adalah bahwa informasi yang dihasilkan dari sistem harus tepat waktu saat dibutuhkan oleh pengguna (Seddon dan Yip, 1992). Laporan sebagai informasi yang berguna dalam pengambilan keputusan harus disediakan secara tepat waktu, agar manajer dapat menindaklanjuti dan mengambil kebijakan yang sesuai. Selain itu, laporan dari aplikasi SAIBA seharusnya dapat dihasilkan secara periodik sebagai dasar melakukan rekonsiliasi dengan KPPN, oleh karena itu hipotesis yang dikembangkan adalah:

H5: Timeliness berpengaruh positif terhadap kepuasan pengguna SAIBA.

Model penelitian tampak pada Gambar 1 di bawah ini:

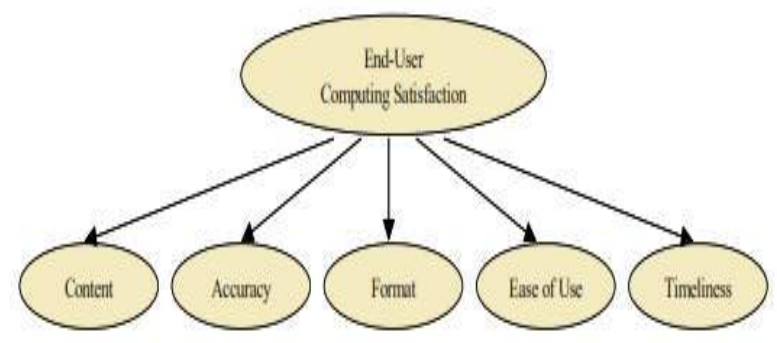

Gambar 1. Kerangka Teoritis

\section{METODOLOGI PENELITIAN}

Populasi dalam penelitian ini adalah operator satuan kerja KPPN di wilayah Provinsi Aceh yang menggunakan SAIBA. Jumlah populasi adalah sebanyak 1460 operator yang terbagi dalam tujuh KPPN yang meliputi KPPN Banda Aceh, KPPN Meulaboh, KPPN Tapaktuan, KPPN Kutacane, KPPN Lhokseumawe, KPPN Langsa dan KPPN Takengon. Mengingat keterbatasan waktu dan tenaga, penelitian terhadap semua populasi tidak dapat dilakukan sehingga penelitian ini dilakukan dengan menggunakan sampel.

Penelitian ini menggunakan metode stratified random sampling, yaitu sampel yang diambil dengan cara memisahkan elemen-elemen populasi ke dalam suatu strata dan memilih secara acak dari masing-masing strata. Berdasarkan rumus Slovin, didapat ukuran sampel minimal dalam penelitian ini adalah sebanyak 312 unit satuan kerja.

Provinsi Aceh dipilih sebagai objek penelitian dikarenakan adanya anomali dalam penerapan SAIBA di awal tahun 2015. Hal tersebut dibuktikan dengan proses rekonsiliasi bulan Januari 2015 pada beberapa KPPN Provinsi Aceh dengan tingkat keterlambatan mencapai lebih dari 40\%, sedangkan pada beberapa KPPN lainnya lingkup Provinsi Aceh tidak terdapat keterlambatan.

Alasan lain dipilihnya operator SAIBA satuan kerja KPPN lingkup Provinsi Aceh sebagai objek penelitian karena karakteristik dan kemampuan akan penggunaan sistem beragam. Sebagian besar operator SAIBA bukan berlatar belakang pendidikan ilmu komputer maupun akuntansi, akan tetapi mereka dituntut untuk menggunakan aplikasi tersebut. Selain itu, tidak sedikit juga operator SAIBA yang sudah berumur senja sehingga kemampuan mereka dalam menggunakan SAIBA juga menjadi beragam.

Seluruh data untuk mengembangkan model penelitian merupakan data primer yang diperoleh dari jawaban kuesioner operator satuan kerja selaku pengguna SAIBA. Pengumpulan data primer menggunakan metode survei melalui kuesioner yang disediakan dalam bentuk online kepada responden. Variabel dependen dalam penelitian ini adalah kepuasan pengguna SAIBA. Variabel independen terdiri dari lima faktor diatas, yakni content, accuracy, format, ease of use dan timeliness. Metode statistik yang digunakan untuk menguji hipotesis adalah regresi berganda dengan bantuan program SPSS 22. Model penelitian untuk menguji hipotesis 1 sampai hipotesis 5 adalah sebagai berikut:

$$
Y=a+b_{1} X_{1}+b_{2} X_{2}+b_{3} X_{3}+b_{4} X_{4}+b_{5} X_{5}+e
$$

\section{Keterangan:}

Y : Kepuasan Pengguna SAIBA

$\mathrm{X}_{1} \quad$ : Dimensi content informasi yang dihasilkan oleh SAIBA

$\mathrm{X}_{2} \quad$ : Dimensi accuracy informasi yang dihasilkan oleh SAIBA

X3 : Dimensi format laporan yang dihasilkan oleh SAIBA

$\mathrm{X}_{4} \quad$ : $\quad$ Dimensi ease of use SAIBA

$\mathrm{X}_{5} \quad$ : Dimensi timeliness informasi yang dihasilkan oleh SAIBA

a : Konstanta

$\mathrm{b}_{1} \quad$ : Koefisien content informasi yang dihasilkan oleh SAIBA

b2 : Koefisien accuracy informasi yang dihasilkan 


\section{oleh SAIBA}

$\mathrm{b}_{3} \quad$ : Koefisien format informasi yang dihasilkan oleh SAIBA

$\mathrm{b}_{4} \quad$ : Koefisien ease of use aplikasi SAIBA

b5 : Koefisien timeliness informasi yang dihasilkan oleh SAIBA

e : tingkat error

\section{HASIL PENELITIAN}

Data dikumpulkan melalui kuesioner yang dikirimkan kepada responden secara online melalui link yang telah disediakan. Kuesioner yang disebarkan berjumlah 314 kuesioner sesuai jumlah sampel, namun dari jumlah tersebut hanya 209 kuesioner yang direspon dan dapat dianalisis. Profil responden pada penelitian ini sebagian besar terdiri dari laki-laki yaitu sebanyak 166 orang $(79,4 \%)$ dari 209 orang responden dan sebagian besar berusia diantara 30-40 tahun sebanyak 117 orang (56\%) dengan mayoritas tingkat pendidikan responden Sarjana Strata 1 (S1) yaitu sebanyak 107 orang (51,2\%). Dilihat dari masa kerja, responden yang menjabat sebagai operator sebagian besar memiliki masa kerja kurang dari 10 tahun yaitu sebanyak 118 orang $(56,4 \%)$.
Setelah memetakan profil responden, dari data yang telah diperoleh dilakukan uji instrumen penelitian. Uji tersebut terdiri dari uji reliabilitas dan uji validitas. Uji reliabilitas diukur dengan menggunakan nilai Cronbach's Alpha dari masingmasing variabel dibandingkan dengan nilai $r_{\text {tabel }}$ product moment menggunakan data uji coba sebanyak 30 responden yang diambil secara acak. Apabila semua variabel dalam model penelitian ini memiliki koefisien reliabilitas Cronbach Alpha lebih besar dari 0,381 maka dapat disimpulkan bahwa semua variabel instrumen penelitian ini handal (reliable).

Pengujian tersebut menghasilkan nilai Cronbach Alpha di atas 0,7 sehingga instrumen penelitian ini dapat diterima. Nilai $r_{\text {hitung }}$ yang dihasilkan juga lebih besar dari $r_{\text {tabel }}$ dan dapat disimpulkan bahwa instrument penelitian ini reliabel. Dari pengujian di atas dapat diartikan bahwa instrumen penelitian ini memiliki kecermatan dan konsistensi untuk mengukur variabel-variabel penelitian sehingga tidak diperlukan modifikasi terhadap instrumen penelitian dan data yang diperoleh dari responden melalui kuesioner dapat digunakan untuk melakukan pengujian hipotesis dan uji asumsi klasik.

\begin{tabular}{|l|c|c|c|}
\hline \multicolumn{1}{|c|}{ Variabel } & $\begin{array}{c}\text { Nilai } \\
\text { Cronbach's } \\
\text { Alpha }\end{array}$ & $\begin{array}{c}\mathrm{N} \\
\text { of } \\
\text { Items }\end{array}$ & Keputusan \\
\hline Content & 0,906 & 4 & Reliabel \\
\hline Accuracy & 0,954 & 2 & Reliabel \\
\hline Format & 0,740 & 2 & Reliabel \\
\hline Ease of use & 0,938 & 2 & Reliabel \\
\hline Timeliness & 0,809 & 2 & Reliabel \\
\hline User Satisfaction & 0,922 & 2 & Reliabel \\
\hline
\end{tabular}

Tabel 1 Hasil Uji Reliabilitas Tiap Variabel

Uji validitas dilakukan dengan membandingkan $r_{\text {hitung }}$ item variabel atas skor totalnya terhadap $r_{\text {tabel }}$ dengan degree of freedom (df)=n-k, dimana $\mathrm{n}$ adalah jumlah sampel dan $\mathrm{k}$ adalah jumlah variabel independen. Dalam penelitian ini, didapat nilai df sebesar jumlah sampel $(\mathrm{n})=30$ dikurangi dengan total variabel independen $(\mathrm{k})=5$, yaitu sebesar 25 . Dengan alpha 0,05 dan uji dua sisi, diperoleh atas df tersebut nilai $r_{\text {tabel }}$ sebesar 0,381. Item suatu variabel dinyatakan

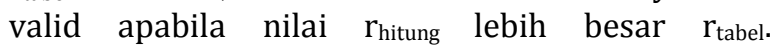

Tabel 2 Hasil Uji Validitas

\begin{tabular}{|ccc|}
\hline Variabel & $\begin{array}{c}\text { Rhitung } \\
\text { Content }\end{array}$ & $\begin{array}{c}\text { Keputusan } \\
0,867 ; 0,927 ; 0,880 ; 0,871\end{array}$ \\
\hline Accuracy & 0,$977 ; 0,979$ & Valid \\
\hline Format & 0,$868 ; 0,920$ & Valid \\
\hline Ease of use & 0,$972 ; 0,969$ & Valid \\
\hline Timeliness & 0,$902 ; 0,936$ & Valid \\
\hline User Satisfaction & 0,$960 ; 0,970$ & Valid \\
\hline
\end{tabular}


Jika data penelitian tersebut telah valid dan reliabel, langkah selanjutnya adalah melakukan uji asumsi klasik yang terdiri dari uji normalitas, uji multikolinearitas dan uji heteroskedastisitas. Uji normalitas dalam penelitian ini menggunakan metode Kolmogorov-Smirnov.

Ghozali (2006) mengatakan bahwa uji Kolmogorov-Smirnov yang menghasilkan angka di atas 0,05 dapat disimpulkan bahwa data tersebut terdistribusi normal. Suatu data dinyatakan normal jika nilai probabilitas (Kolmogorov-Smirnov) lebih besar dari taraf signifikansi yang ditetapkan.

Hasil pengujian normalitas untuk responden yang berasal dari satuan kerja KPPN tipe A1 lingkup Provinsi Aceh didapatkan bahwa data telah terdistribusi normal, hal ini ditunjukkan dengan nilai probabilitas 0,200 yang berarti lebih besar dari taraf signifansi yang ditetapkan sebesar 0,05. Selanjutnya, pengujian normalitas dilakukan terhadap data dari 47 responden yang berasal dari KPPN tipe A2 lingkup Provinsi Aceh dan didapatkan nilai probabilitas sebesar 0,200. Hasil tersebut mengindikasikan bahwa data telah terdistribusi normal.

Uji multikolinearitas dilakukan dengan melihat nilai tolerance atau dengan menggunakan Variance Inflation Factors (VIF). Multikolinearitas akan terjadi apabila nilai VIF diatas 10 atau nilai tolerance di bawah 0,10. Nilai VIF pada masingmasing variabel bebas untuk data responden yang berasal dari KPPN tipe A1 berkisar di bawah 10 dan nilai tolerance pada masing-masing variabel bebas lebih dari 0,1. Berdasarkan hasil pengujian tersebut dapat disimpulkan bahwa tidak terjadi gejala multikolinearitas. Pengujian multikolinearitas juga dilakukan terhadap 47 data responden yang berasal dari satuan kerja KPPN tipe A2 dengan melihat nilai VIF dan nilai Tolerance. Berdasarkan pengolahan data dengan bantuan SPSS, didapatkan nilai VIF kurang dari 10 dan nilai Tolerance lebih besar 0,1. Dapat disimpulkan bahwa tidak terdapat gejala multikolinearitas untuk variabel independen pada 47 data responden yang berasal dari satuan kerja KPPN tipe A2.

Salah satu model yang dapat digunakan untuk uji heteroskedastisitas adalah uji Glejser, dimana gejala heterokedastisitas terjadi jika nilai signifikansi lebih kecil dari 0,05. Pengujian pertama dilakukan terhadap data penelitian yang berasal dari responden satuan kerja KPPN tipe A1. Berdasarkan hasil pengujian, diketahui bahwa seluruh variabel independen bersignifikansi lebih besar dari 0,05 sehingga dapat disimpulkan bahwa tidak terjadi gejala heteroskedastisitas.
Pengujian kedua dilakukan terhadap data penelitian yang berasal dari responden satuan kerja KPPN tipe A2. Menggunakan metode Glejser, dihasilkan nilai signifikansi untuk lima variabel independen lebih besar dari 0,05. Kesimpulan dari pengujian ini bahwa data penelitian yang berasal dari responden satker KPPN tipe A2 tidak terjadi gejala heteroskedastisitas.

Langkah yang dilakukan untuk melakukan uji $\mathrm{t}$ adalah dengan memasukkan semua variabel independen terhadap variabel dependen guna dilakukan uji regresi linear berganda. Proses tersebut akan menghasilkan output berupa tabel koefisien regresi. Apabila signifikansi variabel prediktor kurang dari 0,05 maka dapat disimpulkan bahwa variabel tersebut signifikan. Selain itu, suatu variabel independen juga dinyatakan signifikan jika $t_{\text {hitung }}$ variabel bersangkutan lebih besar dari $t_{\text {tabel. }}$.

Nilai $t_{\text {tabel }}$ ditetapkan untuk taraf signifikansi 0,05 dengan uji dua sisi dan degree of freedom (df) sebesar 157, yaitu didapat dari $\mathrm{n}-\mathrm{k}$ dimana $\mathrm{n}$ adalah jumlah sampel untuk responden KPPN tipe A1 sejumlah 162 dan $\mathrm{k}$ adalah variabel independen dalam penelitian ini yang berjumlah 5 buah dan diperoleh tabel dari df 137 adalah sebesar 1,655.

Tabel 3 Hasil Uji t Data Kelompok Pertama

\begin{tabular}{|c|c|c|c|c|}
\hline $\begin{array}{c}\text { Variabel } \\
\text { Independen }\end{array}$ & $t_{\text {hitung }}$ & $t_{\text {tabel }}$ & $\begin{array}{c}\text { Nilai } \\
\text { signifikan } \\
\text { si }\end{array}$ & $\begin{array}{c}\text { Batas } \\
\text { Maksimal } \\
\text { Signifikan } \\
\text { si }\end{array}$ \\
\hline Content & 1,493 & 1,655 & 0,138 & 0,05 \\
\hline Accuracy & 4,539 & 1,655 & 0,000 & 0,05 \\
\hline Format & 2,253 & 1,655 & 0,026 & 0,05 \\
\hline Ease of use & 4,731 & 1,655 & 0,000 & 0,05 \\
\hline Timeliness &,- 575 & 1,655 & 0,566 & 0,05 \\
\hline
\end{tabular}

Uji $t$ juga dilakukan terhadap data penelitian yang berasal dari 47 responden satker KPPN tipe A2. $T_{\text {tabel }}$ yang ditetapkan dari degree of freedom (df) sebesar 42, yakni jumlah n (47) dikurangi k (5) adalah sebesar 1,682. Hasil uji $t$ untuk data penelitian tersebut disajikan dalam tabel berikut.

Tabel 4 Hasil Uji t Data Kelompok Kedua

\begin{tabular}{|c|c|c|c|c|}
\hline $\begin{array}{c}\text { Variabel } \\
\text { Independen }\end{array}$ & thitung & tabel & $\begin{array}{c}\text { Nilai } \\
\text { signifikansi }\end{array}$ & $\begin{array}{c}\text { Batas } \\
\text { Maksimal } \\
\text { Signifikansi }\end{array}$ \\
\hline Content & 0,392 & 1,682 & 0,697 & 0,05 \\
\hline Accuracy & 0,650 & 1,682 & 0,519 & 0,05 \\
\hline Format & 2,745 & 1,682 & 0,009 & 0,05 \\
\hline Ease of use & 0,079 & 1,682 & 0,937 & 0,05 \\
\hline Timeliness & 3,518 & 1,682 & 0,001 & 0,05 \\
\hline
\end{tabular}

Variabel content merupakan variabel pertama yang digunakan dalam penelitian ini, diketahui sebagai variabel yang tidak berpengaruh signifikan terhadap kepuasan pengguna SAIBA baik untuk 
operator satuan kerja lingkup KPPN tipe A1 maupun KPPN tipe A2. Hasil ini sejalan dengan penelitian yang dilakukan oleh Sekundera (2006), akan tetapi bertolak belakang dengan penelitian Koeswoyo (2006) dan Ilias et al (2009) yang menyatakan bahwa variabel content berpengaruh signifikan terhadap kepuasan pengguna sistem informasi. Hasil penelitian ini menunjukkan bahwa operator satker selaku pengguna SAIBA setelah melakukan entry data dengan SAIBA, mereka tidak memperhatikan isi informasi atau laporan sebagai output dari SAIBA. Terlepas dari isi laporan tersebut sesuai atau tidak dengan yang mereka butuhkan, kepuasan penggunanya tidak akan terpengaruh.

Variabel kedua dalam penelitian ini adalah accuracy. Tingkat akurasi sistem atas masukan (input) terhadap keluaran (output) berupa informasi atau laporan menjadi signifikan bagi kelompok pertama yang berasal dari operator satuan kerja KPPN tipe A1. Hal tersebut senada dengan penelitian Koeswoyo (2006), Sekundera (2006) dan Ilias et al (2009). Dengan keakuratan yang tinggi dari suatu sistem informasi, maka menjadi wajar jika kepuasan pengguna meningkat. Para pengguna SAIBA yang merupakan operator aplikasi satuan kerja tidak menginginkan untuk melakukan perhitungan manual maupun mengecek kembali hasil input terhadap output dan mereka berharap tingkat akurasi sistem tetap tinggi.

Hasil berbeda ditunjukkan kelompok responden kedua yang berasal dari operator satuan kerja KPPN tipe A2. Berdasarkan hasil uji t, diketahui bahwa variabel accuracy tidak memengaruhi kepuasan pengguna SAIBA lingkup KPPN tipe A2. Anggapan mereka bahwa tingkat akurasi sistem bukan faktor berpengaruh dalam menunjang kepuasan pengguna SAIBA didasarkan pada keyakinan mereka bahwa suatu sistem harus mengakomodir keakuratan sehingga tidak akan memengaruhi tingkat kepuasan mereka. Para pengguna cenderung menitikberatkan pada faktor format dibandingkan dengan faktor accuracy.

Format merupakan variabel yang berpengaruh signifikan dalam penelitian ini, baik menurut responden yang berasal dari KPPN tipe A1 maupun KPPN tipe A2, terhadap kepuasan pengguna SAIBA. Hasil ini sesuai dengan penelitian Sekundera (2006) yang menemukan hasil serupa bahwa format berpengaruh signifikan terhadap kepuasan pengguna sistem informasi, akan tetapi berbeda dengan hasil penelitian Koeswoyo (2006) dan Ilias et al (2009). Operator aplikasi satker selaku pengguna SAIBA merasa puas jika format dari laporan yang dihasilkan aplikasi tersebut sesuai dengan yang mereka butuhkan, yaitu mengikuti peraturan yang berlaku. Dengan demikian mereka tidak salah dalam melakukan rekonsiliasi dengan KPPN maupun dalam rangka konsolidasi dengan unit eselon 1 maupun tingkat kementerian/lembaga. Kesalahan dalam format output yang dihasilkan oleh SAIBA akan berbuntut panjang. Para operator dituntut untuk memperbaiki laporan tersebut dan juga harus kembali lagi ke instansi untuk meminta tanda tangan kepala kantor selaku Kuasa Pengguna Anggaran (KPA), selanjutnya mereka melakukan rekonsiliasi ulang ke KPPN dengan laporan yang telah diperbaiki dan ditandatangani KPA. Dengan demikian, variabel format dirasa para operator sebagai faktor paling berpengaruh baik di satker KPPN tipe A1 maupun KPPN tipe A2.

Variabel bebas selanjutnya adalah ease of use, kelompok responden pertama menganggap variabel tersebut berpengaruh signifikan terhadap kepuasan pengguna SAIBA. Kesimpulan yang sama ditemukan dalam penelitian Sekundera (2006) dan Ilias et al (2009). Alasan operator aplikasi satuan kerja KPPN tipe A1 adalah banyaknya operator baru yang mendapatkan tugas menjalankan aplikasi untuk menggantikan staf sebelumnya. Kemudahan penggunaan aplikasi akan membantu mempercepat pekerjaan para operator satuan kerja, oleh karena itu variabel ease of use menjadi faktor yang berpengaruh terhadap kepuasan pengguna SAIBA.

Di lain pihak, faktor ease of use menjadi tidak berpengaruh signifikan untuk kelompok responden yang berasal dari satuan kerja KPPN tipe A2. Hal tersebut didasarkan bahwa mayoritas operator satuan kerja adalah pegawai lama dan sudah berpengalaman dengan aplikasi sehingga faktor ease of use tidak berpengaruh signifikan bagi mereka. Hasil tersebut sejalan dengan hasil penelitian Koeswoyo (2006), Jalil (2008) dan Perdanawati (2014).

Variabel terakhir dalam penelitian ini adalah timeliness. Dalam pengujian terhadap data penelitian dari dua kelompok, responden yang berasal dari satker KPPN tipe A1 mengungkapkan bahwa faktor timeliness tidak memiliki pengaruh signifikan, sedangkan responden yang merupakan operator satuan kerja KPPN tipe A2 menyatakan bahwa faktor timeliness memiliki pengaruh signifikan terhadap kepuasan pengguna SAIBA. Bagi kelompok pertama, kesimpulan tersebut sama dengan penelitian Sekundera (2006). Sementara untuk kelompok kedua, kesimpulan yang didapat dari faktor timeliness sejalan dengan penelitian Ilias et al (2009) yang menyatakan bahwa timeliness tidak berpengaruh signifikan terhadap kepuasan pengguna sistem informasi. 
Perbedaan kesimpulan tersebut dipengaruhi oleh kondisi geografis satuan kerja dan usaha untuk melakukan rekonsiliasi dengan KPPN tepat waktu. Satuan kerja KPPN tipe A2 umumnya berada di lokasi yang jauh dari KPPN untuk melakukan rekonsiliasi maupun dengan Kanwil sebagai unit vertikal di atasnya dalam rangka konsolidasi. Ketepatwaktuan (timeliness) dari SAIBA menjadi acuan mereka untuk meningkatkan kepuasan pengguna.

Dari uraian di atas, dapat ditarik suatu simpulan bahwa lima variabel independen secara simultan berpengaruh signifikan terhadap kepuasan pengguna SAIBA. Mayoritas responden juga merasa puas dengan penggunaan SAIBA dan menyetujui kesuksesan aplikasi tersebut. Perihal perbedaan variabel bebas yang berpengaruh secara parsial baik untuk kelompok pertama maupun kedua, hal ini disebabkan masa kerja responden sebagai operator aplikasi satker dan juga lokasi kantor operator terhadap KPPN menyebabkan kepuasan pengguna dipengaruhi oleh variabel yang berbeda-beda.

Berdasarkan seluruh pengujian di atas dan setelah dilakukan regresi linear berganda maka didapatkan persamaan untuk model penelitian untuk kelompok pertama sebagai berikut.

$$
\begin{aligned}
\mathrm{Y}= & 0,132+0,078 \mathrm{X}_{1}+0,351 \mathrm{X}_{2}+0,2 \mathrm{X}_{3}+0,299 \mathrm{X}_{4}- \\
& 0,052 \mathrm{X}_{5}+\mathrm{e}
\end{aligned}
$$

Sementara untuk model persamaan regresi dalam penelitian yang dilakukan terhadap kelompok responden yang berasal dari satuan kerja KPPN tipe A2 adalah:

$$
\begin{aligned}
Y= & 0,484+0,025 X_{1}+0,070 X_{2}+0,429 X_{3}+0,009 X_{4} \\
& +0,373 X_{5}+e
\end{aligned}
$$

\section{KESIMPULAN}

a. Hasil pengujian menunjukkan bahwa variabel content, accuracy, format, ease of use dan timeliness secara simultan berpengaruh signifikan terhadap kepuasan pengguna SAIBA.

b. Hasil pengujian regresi linier berganda menunjukkan bahwa variabel content secara parsial tidak berpengaruh signifikan terhadap kepuasan pengguna SAIBA. Hal ini terjadi baik di lingkup satker KPPN tipe A1 maupun KPPN tipe A2. Pengguna SAIBA cenderung mengabaikan content dari informasi yang dihasilkan aplikasi tersebut setelah mereka melakukan input data sesuai dengan cara yang semestinya. c. Hasil pengujian lain menunjukkan bahwa variabel accuracy secara parsial berpengaruh signifikan terhadap kepuasan pengguna SAIBA lingkup satker KPPN tipe A1 meskipun di lingkup satker KPPN tipe A2 tidak berpengaruh signifikan. Akurasi menjadi faktor penting dalam menunjang kepuasan pengguna SAIBA di satker KPPN tipe A1 karena mereka tidak ingin melakukan dua kali pekerjaan seperti menghitung secara manual sehingga akurasi yang ada pada SAIBA akan menambah kepuasan mereka. Berbeda halnya dengan satker KPPN tipe A2 yang beranggapan bahwa akurasi dalam suatu sistem informasi menjadi tidak mutlak untuk diakomodir sehingga faktor accuracy tidak memengaruhi kepuasan pengguna SAIBA.

d. Hasil pengujian selanjutnya menunjukkan bahwa variabel format secara parsial berpengaruh signifikan terhadap kepuasan pengguna SAIBA lingkup satker KPPN tipe A1 dan KPPN tipe A2. Hal ini berarti bahwa pengguna SAIBA akan merasa puas jika output yang dihasilkan oleh aplikasi tersebut telah sesuai dengan kebutuhan mereka.

e. Hasil pengujian terhadap variabel ease of use menghasilkan suatu simpulan bahwa variabel tersebut berpengaruh signifikan terhadap kepuasan pengguna SAIBA lingkup satker KPPN tipe A1 karena banyaknya operator baru di instansi mereka. Sebaliknya, pada satker KPPN tipe A2 yang umumnya adalah operator lama, variabel ini tidak berpengaruh signifikan terhadap kepuasan pengguna.

f. Hasil pengujian atas variabel timeliness menyimpulkan bahwa variabel tersebut tidak berpengaruh signifikan bagi satker pada KPPN tipe A1 dikarenakan lokasi KPPN yang tidak begitu jauh dibandingkan dengan jarak satker pada KPPN tipe A2. Oleh karena itu, responden yang berasal dari satker KPPN tipe A2 memandang variabel timeliness sebagai variabel yang berpengaruh signifikan terhadap kepuasan pengguna SAIBA.

\section{DAFTAR REFERENSI}

DeLone, W.H., and E.R.McLean. 1992. Information System Success: The Quest for The Dependent Variable. Information Systems Research. 3: 60-95.

Doll, W.J., \& Torkzadeh, G. 1988. The Measurement of end-user computing satisfaction. MIS Quarterly, Vol. 12, No. 6: 259-274. 
Doll, W.J., Xia, W. and Torkzadeh, G. 1994. A Confirmatory Factor Analysis of the EndUser Computing Satisfaction Instrument. MIS Quarterly. Hal.453-461.

Gupta, M.P., Kanugyo S, Kumar R and Sahu G.P., 2007. A Study of Information Technology Efectiveness in Select Government Organization in India. Journal for Decision Makers. Vol.32 No.2.

Ilias, Azleen., Abd Razaak, Mohd Zulkeflee., Rahman, Rahida Abdul., Yasoa, Mohd Rushdan 2007. The Study of End-User Computing Satisfaction (EUCS) on Computerised Accounting System (CAS) Among Labuan Federal Territory Gevernment Sectors: A Case Study in The Responsibility Centres. Labuan e-Journal of Muamalat and Society. Hal.1-13.

Istianingsih, dan Utami, Wiwik., 2010. Pengaruh Kepuasan Pengguna Sistem Informasi Terhadap Kinerja Individu. Universitas Mercubuana.

McLeod, Raymond. 2004. Sistem Informasi Manajemen. Edisi ke-7. Jakarta: Salemba Empat.

Remenyi, Dan., Money, Arthur., dan SherwoodSmith, Michael. 2001. The Effective Measurement and Management of IT Costs and Benefits. Edisi ke-2. Oxford: Butterworth-Heinemann.

Seddon, P., \& Yip, S.K. 2002. An Empirical Evaluation of User Information Satisfaction (UIS) measures for use with general ledger accounting software. Journal of Information Systems, Vol. 12, No. 2: 49-60.

Republik Indonesia. 2010. Peraturan Pemerintah Nomor 71 Tahun 2010 tentang Standar Akuntansi Pemerintahan.

Kementerian Keuangan Republik Indonesia. 2014. Peraturan Menteri Keuangan Nomor 270/PMK.05/2014 Tahun 2014 tentang Penerapan Standar Akuntansi Pemerintahan Basis Akrual pada Pemerintah Pusat. 